University of Nebraska - Lincoln

DigitalCommons@University of Nebraska - Lincoln

\title{
A Lacustrine Carbonate Record of Holocene Seasonality and Climate
}

\author{
Chad A. Wittkop \\ Department of Chemistry and Geology, Minnesota State University, Mankato, Minnesota 56001, USA, \\ chad.wittkop@mnsu.edu \\ Jane L. Teranes \\ Scripps Institution of Oceanography, Geologic Research Division, University of California-San Diego, 9500 \\ Gilman Drive, La Jolla, California 92093-0244, USA \\ Walter E. Dean \\ U.S. Geological Survey, Earth Surface Processes, Box 25046, MS 980, Federal Center, Denver, Colorado \\ 80225, USA \\ Thomas P. Guilderson \\ Center for Accelerator Mass Spectrometry, Lawrence Livermore National Laboratory, P.O. Box 808, L-397, \\ Livermore, California 94550, USA
}

Follow this and additional works at: https://digitalcommons.unl.edu/usgsstaffpub

Part of the Earth Sciences Commons

Wittkop, Chad A.; Teranes, Jane L.; Dean, Walter E.; and Guilderson, Thomas P., "A Lacustrine Carbonate Record of Holocene Seasonality and Climate" (2009). USGS Staff -- Published Research. 295.

https://digitalcommons.unl.edu/usgsstaffpub/295

This Article is brought to you for free and open access by the US Geological Survey at DigitalCommons@University of Nebraska - Lincoln. It has been accepted for inclusion in USGS Staff -- Published Research by an authorized administrator of DigitalCommons@University of Nebraska - Lincoln. 


\title{
A lacustrine carbonate record of Holocene seasonality and climate
}

\author{
Chad A. Wittkop ${ }^{1, *}$, Jane L. Teranes ${ }^{2}$, Walter E. Dean ${ }^{3}$, and Thomas P. Guilderson ${ }^{4}$ \\ 'Department of Chemistry and Geology, Minnesota State University, Mankato, Minnesota 56001, USA \\ ${ }^{2}$ Scripps Institution of Oceanography, Geologic Research Division, University of California-San Diego, 9500 Gilman Drive, La Jolla, \\ California 92093-0244, USA \\ 3U.S. Geological Survey, Earth Surface Processes, Box 25046, MS 980, Federal Center, Denver, Colorado 80225, USA \\ ${ }^{4}$ Center for Accelerator Mass Spectrometry, Lawrence Livermore National Laboratory, P.O. Box 808, L-397, Livermore, California 94550, USA
}

\begin{abstract}
Annually laminated (varved) Holocene sediments from Derby Lake, Michigan, display variations in endogenic calcite abundance reflecting a long-term (millennial-scale) decrease in burial punctuated with frequent short-term (decadal-scale) oscillations due to carbonate dissolution. Since 6000 cal yr B.P., sediment carbonate abundance has followed a decreasing trend while organic-carbon abundance has increased. The correlation between organic-carbon abundance and the sum of March-April-October-November insolation has an $\boldsymbol{r}^{2}$ value of 0.58. We interpret these trends to represent a precession-driven lengthening of the Holocene growing season that has reduced calcite burial by enhancing net annual organic-matter production and associated calcite dissolution. Correlations with regional paleoclimate records suggest that changes in temperature and moisture balance have impacted the distribution of short-term oscillations in carbonate and organic-matter abundance superimposed on the precession-driven trends.
\end{abstract}

\section{INTRODUCTION}

Seasonal shifts in cycles of temperature and precipitation are manifestations of climate change that may have profound regional consequences (Regonda et al., 2005). Davis (1984) suggested that asynchronous responses of terrestrial vegetation to Holocene climate changes are driven by such seasonal shifts, but few subsequent paleoclimate studies have acknowledged their potential importance. The chronologic precision and biogeochemical sensitivity of annual layers of endogenic carbonate (varves) make them an ideal archive for recording such shifts in seasonal climate.

During summer, temperate lakes with calcareous substrates commonly precipitate endogenic, low-Mg calcite $\left(\mathrm{CaCO}_{3}\right.$; Kelts and $\mathrm{Hsu}$, 1978), which may subsequently be buried as sediment. Previous work has suggested that changes in basin morphometry and allochthonous organic deposition (Dustin et al., 1986), and temperature (Mullins, 1998) may be drivers of long-term (low-frequency) fluctuations in $\mathrm{CaCO}_{3}$ burial. Additional controls on $\mathrm{CaCO}_{3}$ burial include the rate of groundwater recharge (Shapley et al., 2005) and vegetation change, which are linked to climate change. Recent work detailing the dynamics of the lacustrine carbon pumpdefined as the exchange between near-surface production of $\mathrm{CaCO}_{3}$ driven by photosynthetic uptake of $\mathrm{CO}_{2}$, and dissolution of $\mathrm{CaCO}_{3}$ in cold, anoxic bottom waters and sediments driven by the release of $\mathrm{CO}_{2}$ from organicmatter respiration (Dean, 1999; Dean and Schwalb, 2002)—provides a new framework for interpreting seasonal influences on $\mathrm{CaCO}_{3}$ burial.

\section{DERBY LAKE}

Derby Lake, in central Michigan (Fig. 1), has a surface area of 48 ha and a maximum depth of $27 \mathrm{~m}$. A small watershed (94 ha) supplies the lake with overland flow, and the lake has no major inlets and a small outlet (Marsh and Borton, 1974). In summer, the lake displays thermal and chemical stratification typical of many small lakes in the region (Fig. DR1 in the GSA Data Repository ${ }^{1}$ ).

\footnotetext{
*E-mail: chad.wittkop@mnsu.edu.
}

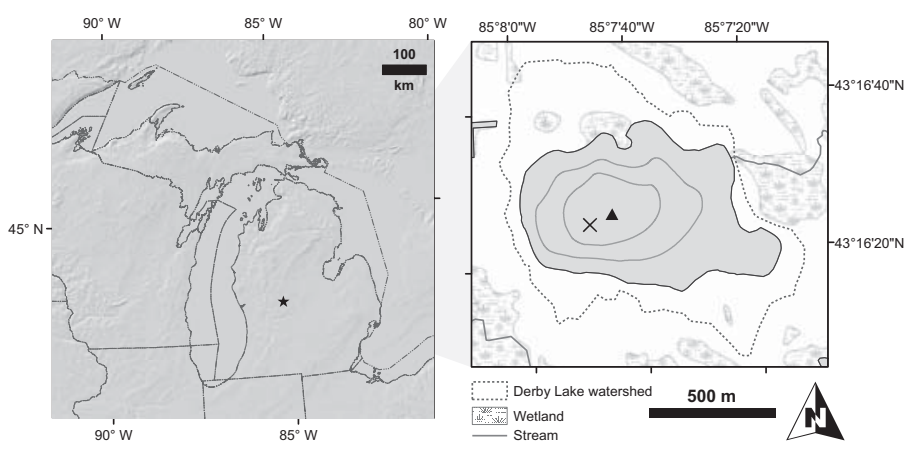

Figure 1. Location of Derby Lake, $43^{\circ} 16^{\prime} 26^{\prime \prime} \mathrm{N}$ lat., $85^{\circ} 7^{\prime} 39^{\prime \prime} \mathrm{W}$ long. (star) in upper Great Lakes region. $X$ marks location of piston core; triangle marks location of freeze core. Bathymetric contour interval $=10 \mathrm{~m}$. Dashed line is extent of lake watershed (Marsh and Borton, 1974).

\section{MATERIALS AND METHODS}

Three piston cores were raised in July 1999 and two in June 2001 using a Kullenberg raft system modified from the design of Kelts et al. (1986). The most complete and least-disturbed core was selected for detailed study. Freeze cores of surface sediments were also collected using a wedge-shaped aluminum box filled with a mixture of dry ice and ethanol (Renberg, 1981). Sediment mineral phases were identified petrographically, by powder X-ray diffraction, and by scanning electron microscopy.

A freeze core collected in 2001 was dated by ${ }^{210} \mathrm{~Pb}$ at the Science Museum of Minnesota St. Croix Watershed Research Station using alphacounting techniques (Eakins and Morrison, 1978). Calendar ages in years A.D. were calculated using a constant-rate-of-supply model (Daniel Engstrom, 2003, personal commun.).

Handpicked charcoal and terrestrial macrofossil fragments were submitted for accelerator mass spectrometry (AMS) radiocarbon dating at Lawrence Livermore National Laboratory. Radiocarbon dates were determined at nine horizons in the freeze core and 14 horizons in the piston core; raw ${ }^{14} \mathrm{C}$ ages were converted to calendar ages (cal yr B.P.) using CALIB software (Rev 4.0; Stuiver and Reimer, 1993; Table 1). Pollen concentrates were dated along with charcoal from two horizons but were not used in the age models due to likely mixing of refractory aquatic organic matter with terrestrial pollen.

Inorganic carbon (IC) and total carbon (TC) abundances in samples collected from the piston and freeze cores at $1 \mathrm{~cm}$ intervals were determined at the U.S. Geological Survey, Denver, Colorado, using a carbon coulometer (Engleman et al., 1985). Percent organic carbon (OC) was determined by difference between TC and IC. The accuracy and precision of this method was $0.10 \mathrm{wt} \%$ for both TC and IC as determined from replicate standards. Percent $\mathrm{CaCO}_{3}$ was determined by dividing percent IC by 0.12 , the molar fraction of carbon in $\mathrm{CaCO}_{3}$.

${ }^{1}$ GSA Data Repository item 2009167, limnological data and LCE detection formula, is available online at www.geosociety.org/pubs/ft2009.htm, or on request from editing@geosociety.org or Documents Secretary, GSA, P.O. Box 9140, Boulder, CO 80301, USA. 


\begin{tabular}{|c|c|c|c|c|c|c|}
\hline CAMS \# & Sample name & $\begin{array}{c}\text { Target } \\
\text { material } \\
(\mathrm{mg} \mathrm{C})\end{array}$ & Description & $\begin{array}{l}\text { Depth } \\
\text { in core } \\
(\mathrm{cm})\end{array}$ & $\begin{array}{c}\text { Radiocarbon ages } \\
\pm \text { standard error } \\
\text { (yr B.P.) }\end{array}$ & $\begin{array}{l}\text { Calibrated ages } \\
\pm \text { standard error } \\
\text { (yr B.P.) }\end{array}$ \\
\hline \multicolumn{7}{|c|}{ Freeze core } \\
\hline 88414 & $31 \mathrm{DL}$ & 0.18 & Small twigs & 16.4 & $115 \pm 45$ & $100 \pm 40$ (A.D. 1850) \\
\hline 88415 & $44 \mathrm{DL}$ & 0.16 & Wood & 22.9 & $225 \pm 30$ & $170 \pm 10($ A.D. 1780$)$ \\
\hline 87245 & $46 \mathrm{DL}$ & $>1$ & Wood & 23.8 & $160 \pm 40$ & $190 \pm 30$ (A.D. 1760) \\
\hline 88417 & $47 \mathrm{DL}$ & 0.39 & Wood/charcoal & 24.3 & $120 \pm 40$ & $200 \pm 45$ (A.D. 1750) \\
\hline 88418 & $55 \mathrm{DL}$ & 0.15 & Wood and leaf fragment & 28.2 & $75 \pm 45$ & $220 \pm 40$ (A.D. 1730) \\
\hline 88420 & $78 \mathrm{DL}$ & 0.28 & Twigs & 41.0 & $240 \pm 40$ & $310 \pm 30$ (A.D. 1640) \\
\hline 88421 & $91 \mathrm{DL}$ & 0.28 & Twigs & 44.0 & $250 \pm 35$ & $320 \pm 30$ (A.D. 1630) \\
\hline 88422 & $93 \mathrm{DL}$ & $>1$ & Wood & 48.5 & $285 \pm 45$ & $430 \pm 35$ (A.D. 1520) \\
\hline 88424 & $115 \mathrm{DL}$ & 0.10 & Charcoal/bark & 62.0 & $645 \pm 50$ & $680 \pm 20$ (A.D. 1370) \\
\hline \multicolumn{7}{|c|}{ Piston core } \\
\hline 62022 & DL99 1K-I 44.5-46 & $>10 \mathrm{mg}$ & Wood & 44 & $200 \pm 40$ & $180 \pm 30$ (A.D. 1770) \\
\hline 70715 & DL99 1K-I 50 & 0.158 & Wood & 50 & $310 \pm 50$ & $320 \pm 15$ (A.D. 1630) \\
\hline 70716 & DL99 1K-I 63 & 0.074 & Leaf fragment & 63 & $290 \pm 80$ & $370 \pm 90($ A.D. 1580$)$ \\
\hline 68226 & DL99 1K-I 78 & 0.20 & Wood/charcoal & 78 & $420 \pm 50$ & $490 \pm 30$ (A.D. 460$)$ \\
\hline 68228 & DL99 1K-II 44 & 0.47 & Twig & 123 & $1160 \pm 40$ & $1070 \pm 30$ (A.D. 880) \\
\hline 68234 & DL99 1K-II 44 (rep) & 0.47 & Twig & 123 & $1170 \pm 40$ & $1100 \pm 45$ (A.D. 850) \\
\hline 70717 & DL99 1K-III 38 & 0.04 & Leaf fragment & 269 & $3630 \pm 150$ & $3960 \pm 150$ \\
\hline 70718 & DL99 1K-III 43 & 0.07 & Charcoal & 274 & $3590 \pm 90$ & $3900 \pm 90$ \\
\hline 73206 & DL99 1K-III 140 & $>1$ & Pollen & 371 & $5750 \pm 50$ & $6530 \pm 40$ \\
\hline 74834 & DL99 1K-III 140 & 0.01 & Charcoal & 371 & $5270 \pm 770$ & $6010 \pm 800$ \\
\hline 74835 & DL99 1K-IV 27 & 0.47 & Pollen & 409 & $6540 \pm 40$ & $7450 \pm 30$ \\
\hline 74836 & DL99 1K-IV 27 & 0.04 & Charcoal & 409 & $6330 \pm 180$ & $7290 \pm 140$ \\
\hline 68229 & DL99 1K-IV 100 & 0.06 & Wood & 482 & $6410 \pm 120$ & $7330 \pm 100$ \\
\hline 73205 & DL99 1K-IV 138 & $>1$ & Pollen & 520 & $7550 \pm 50$ & $8370 \pm 40$ \\
\hline 68230 & DL99 1K-V 87 & 0.07 & Charcoal & 619 & $9260 \pm 140$ & $10,400 \pm 160$ \\
\hline 68231 & DL99 1K-VI 15 & 0.37 & Charcoal & 646 & $9790 \pm 40$ & $11,190 \pm 20$ \\
\hline 62326 & DL 99 1K-CC & $\mathrm{N} / \mathrm{A}$ & Charcoal & 697 & $10,250 \pm 40$ & $12,020 \pm 110$ \\
\hline
\end{tabular}

Monthly insolation values from 9000 to 0 cal yr B.P. were reconstructed with AnalySeries software (Paillard et al., 1996), which applies the calculations of Berger (1978) and Berger and Loutre (1991).

\section{RESULTS}

The ${ }^{210} \mathrm{~Pb}$ and calibrated radiocarbon dates used in construction of the age-depth models increase in age with depth through intervals of undisturbed sediment; a composite of polynomial and linear age models was used to model the age-sediment depth relationship (Fig. 2). Low-Mg calcite $\left(\mathrm{CaCO}_{3}\right)$ occurs as finely to very finely crystalline mud $(0.004-0.062$ $\mathrm{mm}$ ); allochems such as ostracodes, gastropods, or Chara fragments were rarely observed. The sediments occur as millimeter-scale laminations of a light-colored $\mathrm{CaCO}_{3}$ and diatom layer with a dark-colored layer containing amorphous organic matter, some diatoms, and rare silt-sized silicates.
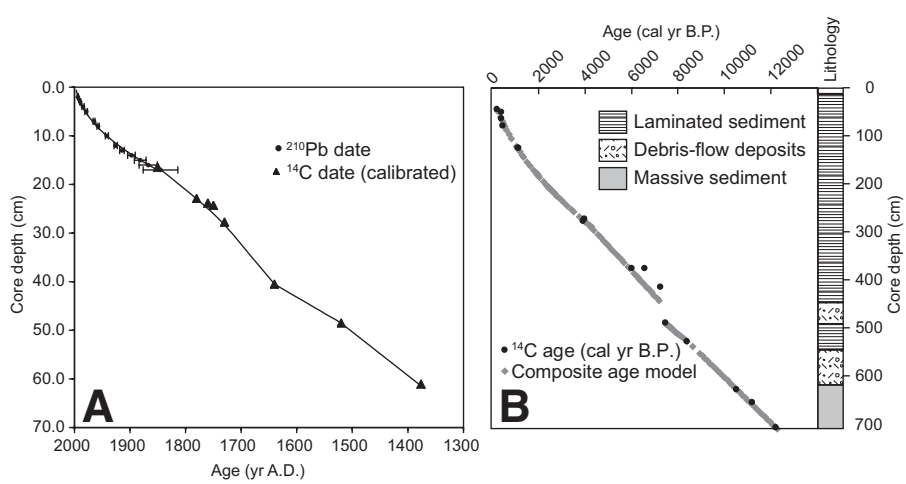

Figure 2. A: Freeze core ${ }^{210} \mathrm{~Pb}$ and calibrated ${ }^{14} \mathrm{C}$ ages (years A.D.), and age models versus depth. B: Piston core calibrated ${ }^{14} \mathrm{C}$ ages (cal yr B.P.) versus depth, age models versus depth, and lithology.
These laminations are assumed to be annual layers (varves), and lamination counts were concordant with radiocarbon age models throughout the piston core (Wittkop, 2004). Two submeter intervals contain massive gray carbonate-rich mud with frequent sand, silt, and intraclasts of laminated sediments or organic matter; these horizons are interpreted to represent the deposits of subaqueous debris flows (Fig. 2).

Percent $\mathrm{CaCO}_{3}$ in the piston core ranges from $2.5 \%$ to $82 \%$, with a mean value of $51 \%$; $\%$ OC ranges from $2.6 \%$ to $19.5 \%$, with a mean value of $6.5 \%$ (Fig. 3). From 8700 to $6000 \mathrm{cal}$ yr B.P., a trend of increasing \% $\mathrm{CaCO}_{3}$ is interrupted by nine brief periods of reduced $\% \mathrm{CaCO}_{3}$, each lasting several decades to just over a century, and each reduction in $\% \mathrm{CaCO}_{3}$ can be paired to an increase in $\%$ OC.

Peak $\% \mathrm{CaCO}_{3}$ occurs near $6000 \mathrm{cal}$ yr B.P. The interval of 6500 4500 cal yr B.P. has generally abundant $\mathrm{CaCO}_{3}$ coupled with low but gradually increasing \% OC, and both $\% \mathrm{CaCO}_{3}$ and $\%$ OC show little variation in this interval. Percent $\mathrm{CaCO}_{3}$ decreases and \% OC increases from 4330 to 1100 cal yr B.P. with considerable high-frequency variation. Low-\% $\mathrm{CaCO}_{3}$ events are common in this interval, and events increase in frequency and amplitude after $2700 \mathrm{cal}$ B.P.

A gap in the $\% \mathrm{CaCO}_{3}$ and \% OC data occurs between 1100 and 590 cal B.P. where water-rich sediments in the upper part of the piston core were disturbed in the field and not sampled. Freeze-core $\% \mathrm{CaCO}_{3}$ data contain several decadal- to centennial-scale oscillations, and peak values of up to $60 \%$ occur in the late nineteenth and early twentieth centuries A.D. (Fig. 3).

\section{CONTROLS ON $\mathrm{CaCO}_{3}$ BURIAL}

\section{Seasonality}

Milankovitch precession has influenced the Holocene rate of $\mathrm{CaCO}_{3}$ burial by altering the length of the OC production season. Increased $\mathrm{OC}$ production, and subsequent export to and decomposition 


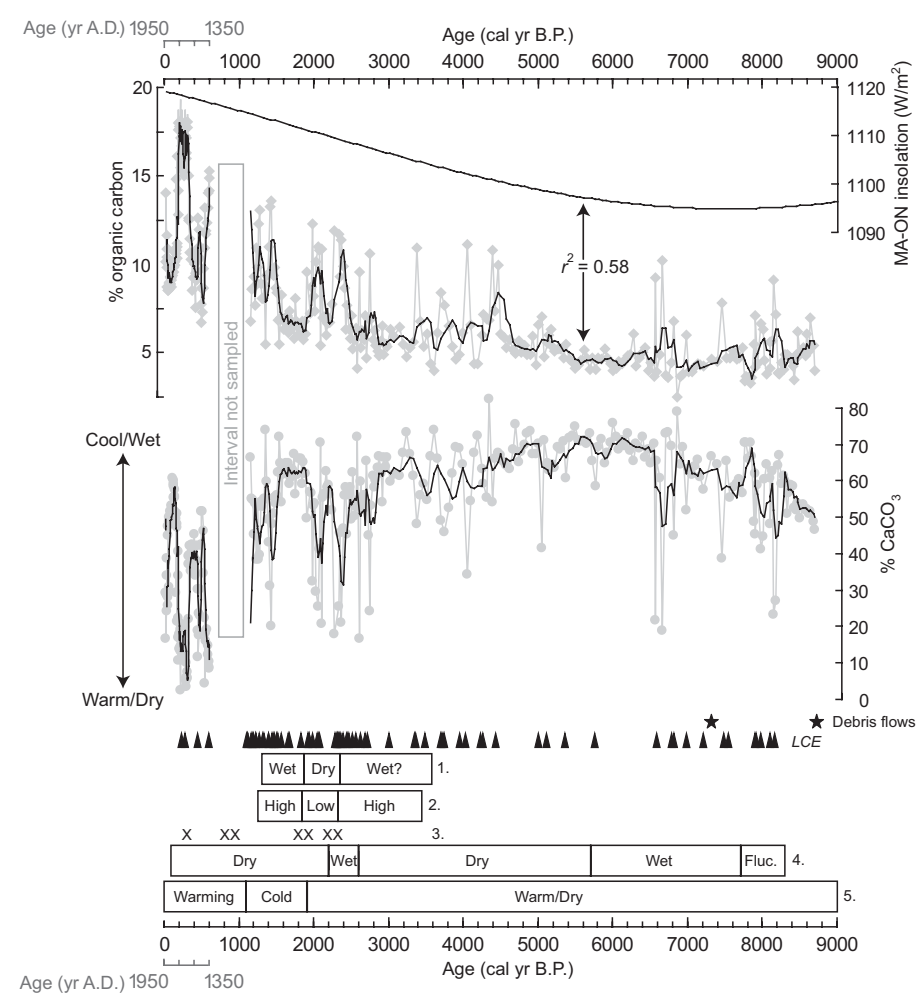

Figure 3. Percent organic carbon (OC) and percent calcium carbonate $\left(\mathrm{CaCO}_{3}\right)$ in Derby Lake piston and freeze cores. Black lines are fivepoint running means. Sum of March, April, October, and November insolation is also shown (Paillard et al., 1996). All data are plotted versus age in calendar yr B.P. (freeze core A.D. scale in gray). Stars denote intervals of debris-flow deposits (not sampled). Black arrows denote locations of decadal-scale low-carbonate events (LCE), interpreted as warm/dry intervals. Boxes show previous interpretations of paleoclimate from Lower Peninsula of Michigan. 1-Bog paleohydrology (Booth and Jackson, 2003). 2-Lake Michigan water level (Baedke and Thompson, 2000). 3-Lake Michigan highstands (Lichter, 1995). 4Pollen and diatom paleolimnology (Fluc.-_period of fluctuating lake levels; Manny et al., 1978). 5-Hydrogen isotopes (Krishnamurthy et al., 1995). Differences in timing and phasing of climatic interpretations likely stem from lower chronologic resolution of previous studies.

in the hypolimnion, lowers the $\mathrm{pH}$ there, creating an environment favorable for $\mathrm{CaCO}_{3}$ dissolution (Dean, 1999; Dean and Schwalb, 2002; Dean et al., 2003).

Orbital theory predicts an enhanced contrast between midlatitude summer and winter insolation and more rapid transitions between these extremes during the early to mid-Holocene (9-4 ka; Kutzbach and Ruddiman, 1993). Insolation during the months of March, April, October, and November was lower in the mid-Holocene before increasing into the late Holocene when seasonality became less extreme (Fig. 3). These months are highlighted because of their potential to host aquatic production at the margins of the Northern Hemisphere growing season and subsequently influence $\mathrm{CaCO}_{3}$ dissolution. In contrast, the sum of summer insolation (May through September) was at a maximum at 9000 cal yr B.P. and has decreased steadily since (Berger, 1978). The sum of March, April, October, and November insolation from 9000 to $0 \mathrm{cal} \mathrm{yr}$ B.P. (MA-ON) is plotted in Figure 3; correlation between MA-ON insolation and Holocene \% OC has an $r^{2}$ value of 0.58 .

Seasonal variation in sunlight is the dominant control on lake primary production at higher latitudes (Lewis, 1996). Primary algal productivity may become significant as early as late March and April, reach peak levels in June, July, and August, and then reduce to winter levels by November (Wetzel, 2001). The mid-Holocene reduction in fall, winter, and spring insolation shortened the aquatic growing season and reduced OC production and accumulation, leading to reduced $\mathrm{CaCO}_{3}$ dissolution.

Increased summer insolation during the same period favored warmwater $\mathrm{CaCO}_{3}$ precipitation. $\mathrm{CaCO}_{3}$ precipitation occurs in summer and is favored by high productivity and warm water conditions (Ohlendorf and Sturm, 2001; Nuhfer et al., 1993). At 7000 cal B.P., summer insolation was more intense (May-October $+3.3 \%$ ) than present, whereas nonsummer insolation was lower (November-April -2.0\%) than present, enhancing $\mathrm{CaCO}_{3}$ and $\mathrm{OC}$ production during the summer, while reducing the amount of $\mathrm{OC}$ produced November through April. This further increased the burial rate by reducing the rate of bottom- and pore-water $\mathrm{CaCO}_{3}$ dissolution.

This insolation-productivity model is a more likely explanation for the mid-Holocene increase in $\mathrm{CaCO}_{3}$ burial in Derby Lake than the bench/ wetland progradation model suggested by Dustin et al. (1986) for Littlefield Lake, Michigan, which called upon progressive development of wetlands in the watershed to increase the ratio of allochthonous $\mathrm{OC}$ to $\mathrm{CaCO}_{3}$ burial through the late Holocene. The wetland progradation model is problematic for Derby Lake because its carbonate benches are less prominent and the small watershed contains insignificant wetlands (Fig. 1).

Insolation-driven variations in seasonality have been suggested as the mechanism for driving asynchronous responses of terrestrial ecosystems at differing elevations to Holocene climate change (Davis, 1984), but this is the first suggestion that sediment records from aquatic systems may also be impacted by variations in nonsummer insolation.

\section{Submillennial Climatic Variability}

The same biogeochemical mechanisms linking long-term $\mathrm{CaCO}_{3}$ burial to seasonality also link short-term variations in $\mathrm{CaCO}_{3}$ burial with changes in Holocene climate. Short-term, low-\% $\mathrm{CaCO}_{3}$ events ranging from a few years to centuries in duration occur throughout the Derby Lake record, with 78 low-\% $\mathrm{CaCO}_{3}$ events between 8700 and 0 cal yr B.P. (Fig. 3 ; detailed in the Data Repository). Low- $\% \mathrm{CaCO}_{3}$ events can be correlated between cores, indicating that conditions producing these events were basinwide rather than localized on the lake bottom. The majority of low-\% $\mathrm{CaCO}_{3}$ events occur after $2700 \mathrm{cal}$ yr B.P., and the fewest events are recorded during the mid-Holocene between 7000 and 4500 cal yr B.P. A similar pattern of Holocene $\mathrm{CaCO}_{3}$ abundance was recently described from the sediments of neighboring Duck Lake (Nelson, 2006), suggesting a common external forcing mechanism driving these events. We interpret low-\% $\mathrm{CaCO}_{3}$ events as representing periods of higher temperatures and/ or reduced precipitation.

The earliest low-\% $\mathrm{CaCO}_{3}$ events are bundled between subaqueous debris-flow deposits (Figs. 2 and 3), suggesting a period of unstable climate and fluctuating lake levels coinciding with the widely reported $8.2 \mathrm{ka}$ event (Alley et al., 1997; Shuman et al., 2002), when zonal westerly winds intensified over the upper U.S. Midwest (Dean et al., 2002). A comparison with Holocene climatic reconstructions from the Lower Peninsula of Michigan (Fig. 3; Manny et al., 1978; Krishnamurthy et al., 1995; Lichter, 1995; Baedke and Thompson, 2000; Booth and Jackson, 2003) suggests some correspondence between periods of low $\% \mathrm{CaCO}_{3}$ and warmer temperatures and/or decreased precipitation, supporting the hypothesis that Derby Lake $\mathrm{CaCO}_{3}$ burial decreases during warmer conditions due to increased $\mathrm{OC}$ production and dissolution-driven reductions in $\mathrm{CaCO}_{3}$ burial. This effect may be compounded by reduced groundwater recharge during dry periods that lower the rate of $\mathrm{Ca}^{2+}$ supply, which also limits $\mathrm{CaCO}_{3}$ production and burial (Shapley et al., 2005). The broad pattern of low-\% $\mathrm{CaCO}_{3}$ events in Derby Lake suggests that the Holocene climate of Michigan was prone to warm and dry events in the early and late Holocene, similar to patterns documented from the northeastern United States (Shuman et al. 2002) but asynchronous with the arid mid-Holocene "prairie period" in the upper Midwest (Grimm and Jacobson, 2004), when $\mathrm{CaCO}_{3}$ burial was greatest in Derby Lake. 
The increase in occurrence of low- $\% \mathrm{CaCO}_{3}$ events through the late Holocene may also have resulted from intensifying decadal-scale climatic variability through this time. Proxy data (Rodbell et al., 1999) and modeling (Bush, 1999) demonstrate that the El Niño-Southern Oscillation (ENSO) cycle behaved differently during the early and middle Holocene, and Moy et al. (2002) suggested that ENSO events increased in frequency and intensity from the mid-Holocene to $1200 \mathrm{cal}$ B.P., before tapering back to levels experienced in the modern system. However, the increase in frequency and amplitude of low- $\% \mathrm{CaCO}_{3}$ events in the late Holocene is also consistent with a gradual, seasonality-driven shift in the carbonate-organic balance toward carbonate dissolution, where a longer growing season favors organic-matter production and calcite dissolution. Alternatively, in-lake dynamics such as basin filling, sediment focusing, and eutrophication may partly explain these changes. Further multiproxy paleolimnological analysis is required to evaluate the roles of these competing forcing factors.

\section{CONCLUSION}

Our work suggests that millennial-scale variations in seasonality govern long-term, meter-scale changes in carbonate abundance by altering the length and intensity of the aquatic growing season and carbonate dissolution. A similar mechanism may link short-term warm and dry events with low-carbonate horizons that occur throughout the Holocene record in Derby Lake. This record demonstrates the potential of lacustrine carbonate systems to respond to and record long-term seasonal shifts in climate as well as short-term environmental changes. If the detailed structure of the Derby Lake $\mathrm{CaCO}_{3}$ record is indeed a signal of external environmental changes, it displays more complexity in the Holocene climate of the region than existing paleorecords have demonstrated.

\section{ACKNOWLEDGMENTS}

This work was supported by National Science Foundation-Division of Atmospheric Sciences grant NSF-ATM 9980380 (to Kerry Kelts), and by the U.S. Geological Survey Earth Surface Dynamics Program (Dean). Discussions with Thomas C. Johnson and H.E. Wright Jr. shaped key portions of this work. We thank David Chapman, Lesleigh Anderson, Randy Schumann, and two anonymous reviewers, whose comments improved the manuscript significantly.

\section{REFERENCES CITED}

Alley, R.B., Mayewski, P.A., Sowers, T., Stuiver, M., Taylor, K., and Clark, P.U., 1997, Holocene climatic instability: A prominent, widespread event $8200 \mathrm{yr}$ ago: Geology, v. 25 , p. 483-486, doi: 10.1130/0091-7613(1997)025<0483:HCIAPW>2.3.CO;2.

Baedke, S.J., and Thompson, T.A., 2000, A 4,700-year record of lake level and isostasy for Lake Michigan: Journal of Great Lakes Research, v. 26, p. 416-426.

Berger, A., 1978, Long-term variations of daily insolation and Quaternary climatic change: Journal of the Atmospheric Sciences, v. 35, p. 2362-2367, doi: 10.1175/1520-0469(1978)035<2362:LTVODI>2.0.CO; 2 .

Berger, A., and Loutre, M.-F., 1991, Insolation values for the climate of the last 19 million years: Quaternary Science Reviews, v. 10, p. 297-317, doi: 10.1016/02773791(91)90033-Q.

Booth, R.K., and Jackson, S.T., 2003, A high-resolution record of late-Holocene moisture variability from a Michigan raised bog, USA: The Holocene, v. 13, p. 863 876, doi: 10.1191/0959683603hl669rp.

Bush, A.B.G., 1999, Assessing the impact of mid-Holocene insolation on the atmosphere-ocean system: Geophysical Research Letters, v. 26, p. 99-102, doi: 10.1029/1998GL900261.

Davis, O.K., 1984, Multiple thermal maxima during the Holocene: Science, v. 225, p. 617-619, doi: 10.1126/science.225.4662.617.

Dean, W.E., 1999, The carbon cycle and biogeochemical dynamics in lake sediments: Journal of Paleolimnology, v. 21, p. 375-393, doi: 10.1023/A:1008066118210.

Dean, W.E., and Schwalb, A., 2002, The lacustrine carbon cycle as illuminated by the waters and sediments of two hydrologically distinct headwater lakes in northcentral Minnesota, U.S.A.: Journal of Sedimentary Research, v. 72, p. 416-431, doi: 10.1306/101801720416.

Dean, W.E., Forester, R.M., and Bradbury, J.P., 2002, Early Holocene change in atmospheric circulation in the northern Great Plains: An upstream view of the $8.2 \mathrm{ka}$ cold event: Quaternary Science Reviews, v. 21, p. 1763-1775.

Dean, W.E., Neff, B.P., Rosenberry, D.O., Winter, T.C., and Parkhurst, R., 2003, The significance of ground water to the accumulation of iron and manganese in the sediments of two hydrologically distinct lakes in north-central Minnesota: A geological perspective: Ground Water, v. 41, p. 951-963, doi: 10.1111/j.17456584.2003.tb02437.x.

Dustin, N.M., Wilkinson, B.H., and Owen, R.M., 1986, Littlefield Lake, Michigan: Carbonate budget of Holocene sedimentation in a temperate-region lacustrine system: Limnology and Oceanography, v. 31, p. 1301-1311.
Eakins, J.D., and Morrison, R.T., 1978, A new procedure for the determination of lead-210 in lake and marine sediments: The International Journal of Applied Radiation and Isotopes, v. 29, p. 531-536, doi: 10.1016/0020-708X(78)90161-8.

Engleman, E.E., Jackson, L.L., Norton, D.R., and Fischer, A.G., 1985, Determination of carbonate carbon in geological materials by coulometric titration: Chemical Geology, v. 53, p. 125-128, doi: 10.1016/0009-2541(85)90025-7.

Grimm, E.C., and Jacobson, G.L., Jr., 2004, Late-Quaternary vegetation history of the eastern United States, in Gillespie, A.R., Porter, S.C., and Atwater, B.F., eds., The Quaternary Period in the United States, 1: Elsevier Developments in Quaternary Science, v. 1: Amsterdam, Elsevier B.V., p. 381-402.

Kelts, K., and Hsu, K., 1978, Freshwater carbonate sedimentation, in Lerman, A., ed., Lakes: Physics, Chemistry, Geology: Berlin, Springer, p. 295-323.

Kelts, K.R., Briegel, U., Ghilardi, K., and Hsu, K., 1986, The limnogeology-ETH coring system: Schweizerische Zeitschrift für Hydrologie, v. 48, p. 104-115, doi: 10.1007/ BF02544119.

Krishnamurthy, R.V., Syrup, K.A., Baskaran, M., and Long, A., 1995, Late glacial climate record of Midwestern United States from the hydrogen isotope ratio of lake organic matter: Science, v. 269, p. 1565-1567, doi: 10.1126/science.269.5230.1565.

Kutzbach, J.E., and Ruddiman, W.F., 1993, Model description, external forcing, and surface boundary conditions, in Wright, H.E., Jr., Kutzbach, J.E., Webb, T., III, Ruddiman, W.F., Street-Perrott, F.A., and Bartlein, P.J., eds., Global climates since the Last Glacial Maximum: Minneapolis, University of Minnesota Press, p. 12-23.

Lewis, W.M., Jr., 1996, Tropical lakes: How latitude makes a difference, in Schiemer, F., and Boland, K.T., eds., Perspectives in Tropical Limnology: Amsterdam, SBP Academic, p. 43-64.

Lichter, J., 1995, Lake Michigan beach-ridge and dune development, lake level, and variability in regional water balance: Quaternary Research, v. 44, p. 181-189, doi: 10.1006/qres.1995.1062.

Manny, B.A., Wetzel, R.G., and Bailey, R.E., 1978, Paleolimnological sedimentation of organic carbon, nitrogen, phosphorous, fossil pigments, pollen, and diatoms in a hypereutrophic, hardwater lake: A case history of eutrophication: Polskie Archiwum Hydrobiologii, v. 25, p. 243-267.

Marsh, W.M., and Borton, T.E., 1974, Inland Lakes of Michigan and Their WatershedsAn Atlas: Lansing, Michigan Department of Natural Resources, $166 \mathrm{p}$.

Moy, C.M., Seltzer, G.O., Rodbell, D.T., and Anderson, D.M., 2002, Variability of El Niño/Southern Oscillation activity at millennial timescales during the Holocene epoch: Nature, v. 420, p. 162-165, doi: 10.1038/nature01194.

Mullins, H.T., 1998, Environmental change controls of lacustrine carbonate, Cayuga Lake, New York: Geology, v. 26, p. 443-446, doi: 10.1130/0091-7613(1998)026<0443:ECCOLC $>2.3 . \mathrm{CO} ; 2$.

Nelson, J.A., 2006, Cyclic Deposition of Carbonate and Organic Matter in Holocene Lacustrine Sediment, Lower Michigan, USA [M.S. thesis]: Indianapolis, Indiana University, $46 \mathrm{p}$.

Nuhfer, E.B., Anderson, R.Y., Bradbury, J.P., and Dean, W.E., 1993, Modern sedimentation in Elk Lake, Clearwater County, Minnesota, in, Bradbury, J.P., and Dean W.E., eds., Elk Lake, Minnesota: Evidence for Rapid Climate Change in the NorthCentral United States: Geological Society of America Special Paper 276, p. 75-96.

Ohlendorf, C., and Sturm, M., 2001, Precipitation and dissolution of calcite in a Swiss high alpine lake: Arctic, Antarctic, and Alpine Research, v. 33, p. 410-417, doi: 10.2307/1552550.

Paillard, D., Labeyrie, L., and Yiou, P., 1996, Macintosh program performs time-series analysis: Eos (Transactions, American Geophysical Union), v. 77, p. 379, doi: 10.1029/96EO00259.

Regonda, S.K., Rajagopalan, B., Clark, M., and Pitlick, J., 2005, Seasonal cycle shifts in hydroclimatology over the western United States: Journal of Climate, v. 18, p. 372 384, doi: 10.1175/JCLI-3272.1.

Renberg, I., 1981, Improved methods for sampling, photographing, and varve-counting of varved lake sediments: Boreas, v. 10, p. 255-258.

Rodbell, D.T., Seltzer, G.O., Anderson, D.M., Abbot, M.B., Enfield, D.B., and Newman, J.H., 1999, An 15,000-year record of El Niño-driven alluviation in southwestern Ecuador: Science, v. 283, p. 516-520, doi: 10.1126/science.283.5401.516.

Shapley, M., Eto, I., and Donovan, J.J., 2005, Endogenic calcium carbonate flux in groundwater-controlled lakes: Implications for lacustrine paleoclimate records: Geochimica et Cosmochimica Acta, v. 69, p. 2517-2533, doi: 10.1016/j.gca.2004.12.001.

Shuman, B., Bartlein, P.J., Logar, N., Newby, P., and Webb, T., III, 2002, Parallel climate and vegetation responses to the early Holocene collapse of the Laurentide ice sheet: Quaternary Science Reviews, v. 31, p. 1793-1805, doi: 10.1016/S02773791(02)00025-2.

Stuiver, M., and Reimer, P.J., 1993, Extended ${ }^{14} \mathrm{C}$ database and revised CALIB radiocarbon calibration program: Radiocarbon, v. 35, p. 215-230.

Wetzel, R.G., 2001, Limnology: Lake and River Ecosystems: San Diego, Academic Press, $1006 \mathrm{p}$.

Wittkop, C.A., 2004, Paleoenvironmental Reconstruction Using Laminated Sediments Containing Authigenic Carbonate Minerals: Case Studies from the Great Lakes Region of North America [Ph.D. thesis]: Minneapolis, University of Minnesota, 203 p.

Manuscript received 25 April 2008

Revised manuscript received 20 January 2009

Manuscript accepted 22 March 2009

Printed in USA 